\title{
OXIDATIVE DEGRADATION OF 2-CHLOROPHENOL BY PERSULFATE
}

\author{
Krzysztof Kuśmierek' ${ }^{1}$ Andrzej Świątkowski ${ }^{1}$, Lidia Dąbek²
}

1 Institute of Chemistry, Military University of Technology, Kaliskiego 2, 00-908 Warsaw, Poland. e-mail: krzysztof.kusmierek@wat.edu.pl; a.swiatkowski@wp.pl

2 Faculty of Environmental Engineering, Geomatics and Power Engineering, Kielce University of Technology, al. Tysiąclecia Państwa Polskiego 7, 25-314 Kielce, Poland, e-mail: Idabek@tu.kielce.pl

Received: 2015.04.01 Accepted: 2015.06.02 Published: 2015.07.01

\begin{abstract}
The degradation of 2-chlorophenol (2-CP) by persulfate was investigated. The kinetics of persulfate oxidation of 2-chlorophenol in aqueous solutions at various $\mathrm{pH}$, oxidant concentration, temperature, $\mathrm{Fe}^{2+}$ and $\mathrm{Cu}^{2+}$ ions content was studied. Maximum of 2-CP degradation occurred at $\mathrm{pH}$ 8. The oxidation rate of 2-CP increased with increasing the persulfate molar excess. The degradation process was significantly influenced by temperature - the higher temperature results in a faster degradation of 2-CP. The activation of persulfate by ferrous and copper ions was also studied. Results showed that persulfate is activated more effectively by iron(II) than copper(II) ions. A comparison of different persulfate activation methods revealed that heat-activation was the most effective. Under optimal conditions, in the presence of ferrous ions at $50{ }^{\circ} \mathrm{C}$, complete degradation of 2-chlorophenol was achieved after about 30 minutes.
\end{abstract}

Keywords: chlorophenol, oxidation, persulfate.

\section{INTRODUCTION}

Chlorophenols are organic compounds of cyclic aromatics formed by replacing hydrogen atoms in phenol molecule with chlorine atoms. They can be introduced into the water and soil from various sources, such as wood and fibers preservatives, pesticides [Czaplicka 2004, Armenante et al. 1999] or as possible by-products of drinking water disinfection [Ahlborg and Thunberg 1980]. Because of the long persistence and high toxicity of chlorophenols, it is very important to reduce the input of these toxic chemicals into the environment and to study methods for their removal from contaminated sites.

Different methods for the removal of chlorophenols from water are reported. Among them the oxidation methods, especially advanced oxidation processes (AOPs) [Pera-Titus et al. 2004, Kucharska and Naumczyk 2009, Kuśmierek and Świątkowski 2012], are widely used. AOPs are processes involving the generation of highly reactive oxidizing species (mainly hydroxyl radicals, $\mathrm{HO}^{\circ}$ ), able to attack and degrade organic compounds. Free radicals in AOPs, are produced generally by photolysis, heterogeneous catalysis, ozonation and ozone related processes $\left(\mathrm{O}_{3} / \mathrm{H}_{2} \mathrm{O}_{2}\right.$, $\mathrm{UV} / \mathrm{O}_{3}$ ), and methods based on hydrogen peroxide $\left(\mathrm{H}_{2} \mathrm{O}_{2} / \mathrm{UV}\right.$, Fenton: $\mathrm{H}_{2} \mathrm{O}_{2} / \mathrm{Fe}^{2+} / \mathrm{Fe}^{3+}$, Fentonlike processes) [Pera-Titus et al. 2004].

The purpose of this study is to examine the degradation of 2-chlorophenol (2-CP) by persulfate as an alternative to the commonly used advanced oxidation processes. Persulfate salts have been applied as oxidants for the degradation of various organic compounds including polyvinyl alcohol [Oh et al. 2009], trichloroethylene [Liang et al. 2007], methyl tert-butyl ether [Huang et al. 2002, Liang et al. 2010], phenol [Mora et al. 2011, Olmez-Hanci and Arslan-Alaton 2013], bisphenol A [Jiang et al. 2013, Olmez-Hanci et al. 2013], 2,4-dinitrotoluene [Oh et al. 2011], $p$-chloroaniline [Liang et al. 2013], ibuprofen [Ghauch et al. 2012a], polychlorinated biphenyls [Fang et al. 2013], dyes [Yang et al. 2010, Ghauch et al. 2012b], and some pesticides [Cao et al. 2009, Tan et al. 2012, Liu et al. 2012, Liang et al. 2014]. 
Persulfate salts (e.g. sodium, potassium or ammonium persulfate) dissociate in water to the persulfate anion $\mathrm{S}_{2} \mathrm{O}_{8}{ }^{2-}$. Standard redox potential of persulfate ion is $2.1 \mathrm{~V}$, which is lower than that of hydroxyl radicals $(2.8 \mathrm{~V})$ and atomic oxygen $(2.4 \mathrm{~V})$ but comparable with ozone $(2.1 \mathrm{~V})$ and higher than those of hydrogen peroxide $(1.8 \mathrm{~V})$, permanganate $(1.7 \mathrm{~V})$ or chlorine dioxide $(1.5 \mathrm{~V})$ [Latimer 1952, Krzemińska et al. 2015].

Moreover, persulfate is a non-selectively reactive, relatively stable at room temperature and has a relatively long lifetime in water, as compared to the hydrogen peroxide and ozone [Huang et al. 2002, Liu et al. 2012]. The reaction of organic compounds with persulfate ions is kinetically slow, therefore, they are generally activated to generate the intermediate sulfate free radicals which are a stronger oxidant $(2.6 \mathrm{~V})$ than persulfate anions [Latimer 1952]. To enhance the oxidation of contaminants persulfate oxidation is conducted under heat or light conditions (Eq. 1) or in presence of metal ions (Eq. 2), such as $\mathrm{Fe}^{2+}$ or $\mathrm{Cu}^{2+}$ [Kolthoff et al. 1951, Berlin 1986].

$$
\begin{gathered}
\mathrm{S}_{2} \mathrm{O}_{8}{ }^{2-}+\text { heat } / \mathrm{UV} \rightarrow 2 \mathrm{SO}_{4}^{\cdot^{-}} \\
\mathrm{S}_{2} \mathrm{O}_{8}{ }^{2-}+\mathrm{Me}^{\mathrm{n}+} \rightarrow \mathrm{SO}_{4}{ }^{\cdot-}+\mathrm{SO}_{4}{ }^{2-}+\mathrm{Me}^{\mathrm{n}+1}
\end{gathered}
$$

So formed sulfate radicals initiates a chain of reactions, involving other radicals and oxidants, where organic compounds are usually degraded (Eq. 3-8) [Huang et al. 2002, Kolthoff et al. 1951].

$$
\begin{aligned}
& \mathrm{SO}_{4} \cdot{ }^{-}+\mathrm{H}_{2} \mathrm{O} \leftrightarrow \mathrm{HO}^{\cdot}+\mathrm{H}^{+}+\mathrm{SO}_{4}^{2-}
\end{aligned}
$$

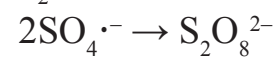

$$
\begin{aligned}
& \mathrm{SO}_{4} \cdot{ }^{-}+\mathrm{HO}^{\cdot} \rightarrow \mathrm{HSO}_{5}^{-} \\
& 2 \mathrm{HO}^{\circ} \rightarrow \mathrm{H}_{2} \mathrm{O}_{2} \\
& \mathrm{H}_{2} \mathrm{O}_{2} \rightarrow \mathrm{H}_{2} \mathrm{O}+1 / 2 \mathrm{O}_{2} \\
& \mathrm{H}_{2} \mathrm{O}_{2}+\mathrm{S}_{2} \mathrm{O}_{8}{ }^{2-} \rightarrow 2 \mathrm{H}^{+}+2 \mathrm{SO}_{4}^{2-}+\mathrm{O}_{2}
\end{aligned}
$$

The potential use of persulfate oxidation of chlorophenols was previously described by Zhao et al. [2010] and Rastogi et al. [2009]. Zhao et al. [2010] described an efficient method for oxidation of 4-chlorofenol by sulfate radicals formed in zero-valent iron mediated decomposition of peroxydisulfate. Rastogi et al. [2009] evaluated the effectiveness of three chelating agents (citrate, ethylenediaminedisuccinate and pyrophosphate) on $\mathrm{Fe}^{2+}$-mediated activation of persulfate at neutral $\mathrm{pH}$ conditions and, in consequence, degradation of 4-chlorophenol. Recently, the degradation of 2,4-dichlorophenol and 2,4-dichlorophenoxyacetic acid by persulfate under various activation conditions was also reported [Kuśmierek et al. 2015].
In this study we focused on the thermal activation of persulfate to 2-chlorophenol oxidation. The kinetics and reaction conditions influencing the 2-CP degradation with heat-assisted persulfate oxidation were studied. The combination of several factors (e.g. pH, iron(II) or copper(II) ions, elevated temperature) on rate and extent of 2-chlorophenol degradation was also investigated.

\section{MATERIALS AND METHODS}

\section{Chemicals and reagents}

The 2-chlorophenol (2-CP) was purchased from Sigma (St Louis, MO, USA). Acetic acid, ammonium persulfate, sodium hydrogen phosphate heptahydrate, sodium dihydrogen phosphate dihydrate, iron(II) sulfate heptahydrate and copper(II) sulfate pentahydrate were from Avantor Performance Materials (Gliwice, Poland). HPLC-grade acetonitrile was obtained from Acros Organics (Geel, Belgium). Stock solutions of 2-CP $\left(1 \mathrm{mmol} \mathrm{L}^{-1}\right),\left(\mathrm{NH}_{4}\right)_{2} \mathrm{~S}_{2} \mathrm{O}_{8}\left(1 \mathrm{~mol} \mathrm{~L}^{-1}\right)$ $\mathrm{FeSO}_{4} \cdot 7 \mathrm{H}_{2} \mathrm{O}\left(0.1 \mathrm{~mol} \mathrm{~L}^{-1}\right)$ and $\mathrm{CuSO}_{4}(0.1 \mathrm{~mol}$ $\left.\mathrm{L}^{-1}\right)$ were prepared by dissolving the appropriate weights in deionized water. Phosphate buffers $\left(0.2 \mathrm{~mol} \mathrm{~L}^{-1}\right)$ were prepared by mixing $0.2 \mathrm{~mol} \mathrm{~L}^{-1}$ $\mathrm{Na}_{2} \mathrm{HPO}_{4} \cdot 7 \mathrm{H}_{2} \mathrm{O}$ and $0.2 \mathrm{~mol} \mathrm{~L}-1 \mathrm{NaH}_{2} \mathrm{PO}_{4} \cdot 2 \mathrm{H}_{2} \mathrm{O}$. The $\mathrm{pH}$ of the buffers was adjusted by potentiometric titrations.

\section{Oxidation experiments}

Experiments were conducted in a $10 \mathrm{~mL}$ glass volumetric flasks. For each batch experiment, the initial concentration of 2-chlorophenol was 0.1 $\mathrm{mmol} \mathrm{L}{ }^{-1}$. All of the experiments were carried out in two replicates, the mean values of which are reported.

To investigate the effect of $\mathrm{pH}$ on 2-chlorophenol oxidation glassy flasks containing $1 \mathrm{~mL}$ of 2-CP $\left(1 \mathrm{mmol} \mathrm{L}^{-1}\right)$ and $0.1 \mathrm{~mL}$ of persulfate $\left(1 \mathrm{~mol} \mathrm{~L}^{-1}\right)$ were diluted to the volume of $10 \mathrm{~mL}$ with water ( $\mathrm{pH} 2.5$ ), $0.2 \mathrm{~mol} \mathrm{~L}^{-1} \mathrm{NaH}_{2} \mathrm{PO}_{4} \cdot 2 \mathrm{H}_{2} \mathrm{O}$ (pH 5.0) or one of the three phosphate buffers ( $\mathrm{pH}$ $7.0,8.0$ or 9.0 ).

To study the effect of initial persulfate concentration to glassy flasks containing $0.1 \mathrm{mmol} \mathrm{L}^{-1}$ of 2-CP an appropriate amounts of ammonium persulfate $\left(1 \mathrm{~mol} \mathrm{~L}^{-1}\right)$ were added. The experiments were conducted in phosphate buffer $(\mathrm{pH} 8.0)$ at $20^{\circ} \mathrm{C}$. The $2-\mathrm{CP} / \mathrm{S}_{2} \mathrm{O}_{8}{ }^{2-}$ molar ratio was $1 / 10$, $1 / 50,1 / 100,1 / 200,1 / 300$ and $1 / 400$, respectively. 
For comparison, one sample (1/200) was repeated in water $(\mathrm{pH}=2.5)$. At selected time intervals, a $10 \mu \mathrm{L}$ sample from each duplicate flask was collected for 2-CP determination.

To evaluate the effect of temperature on the oxidation of 2-chlorophenol in the persulfate-water or persulfate-phosphate buffer ( $\mathrm{pH} 8.0$ ) systems, the temperature was maintained at 20,30, 40 , and $50^{\circ} \mathrm{C}$ (water bath). Molar ratio of 2-CP to persulfate was $1 / 100,1 / 200$ and $1 / 400$, respectively. Concentrations of 2-CP in solutions were measured after $0.25,0.5,1,2,3,4,5$ and $6 \mathrm{~h}$.

To examine the effect of $\mathrm{Fe}^{2+}$ and $\mathrm{Cu}^{2+}$ ions on 2-chlorophenol oxidation by persulfate, a pre-determined amount of $\mathrm{FeSO}_{4} \cdot 7 \mathrm{H}_{2} \mathrm{O}$ or $\mathrm{CuSO}_{4} \cdot 5 \mathrm{H}_{2} \mathrm{O}$ was added to the 2-CP/persulfate (molar ratio $1 / 200$ ) solution. To obtain the optimal persulfate ratio to iron(II) or copper(II) ions, the experiments were carried out under various $\mathrm{S}_{2} \mathrm{O}_{8}{ }^{2-}$ to metal ion molar ratios $(200 / 0.5,200 / 1,200 / 2)$. The synergistic effect of elevated temperature on the oxidation of 2-CP in the persulfate- $\mathrm{Fe}^{2+}$ or persulfate- $\mathrm{Cu}^{2+}$ water system was also investigated at $50{ }^{\circ} \mathrm{C}$.

\section{Analytical method}

For determination of 2-CP in aqueous solutions a high-performance liquid chromatography method with UV detection was used (Shimadzu LC-20, Kyoto, Japan). The chromatographic analyses were carried out under isocratic conditions using a Phenomenex Luna C18, $1.0 \times 100 \mathrm{~mm}, 3$ $\mu \mathrm{m}$ column (Torrance, CA, USA). The chromatographic conditions were as follow: mobile phase - acetonitrile/water adjusted to $\mathrm{pH} 3.0$ with acetic acid $(40 / 60, v / v)$; flow rate $0.15 \mathrm{~mL} \mathrm{~min}^{-1}$ and de- tector wavelength $274 \mathrm{~nm}$. Five $\mu \mathrm{L}$ of the sample was injected into the chromatographic column. The calibration range was $0.01-0.12 \mathrm{mmol} \mathrm{L} \mathrm{L}^{-1}$. The calibration curves were constructed by plotting peak height vs. 2-CP concentration and the curves were fitted by least squares linear regression analysis. The equation for the linear regression line and $R^{2}$ coefficient were $y=319.46 x+0.22$ and 0.999 , respectively.

\section{RESULTS AND DISCUSSION}

\section{Effect of initial $\mathrm{pH}$}

For investigation of influence of $\mathrm{pH}$ on 2-chlorophenol degradation, experiments were conducted under ambient temperature at initial $\mathrm{pH}$ values of 2.5, 5.0, 7.0, 8.0 and 9.0. The 2-CP to persulfate molar ratio was $1 / 100$. The results are presented in Figure 1.

As it can be seen, degradation of 2-CP with persulfate is strongly $\mathrm{pH}$ dependent. After 24 hours, at $\mathrm{pH} 2.5,5.0,7.0,8.0$ and 9.0, about 1 , $2,42,91$ and $61 \%$ of $2-\mathrm{CP}$ has been degraded, respectively. The oxidation increased with an increase in the $\mathrm{pH}$ value and reaches a maximum value at a $\mathrm{pH}$ of 8.0. The increase of $\mathrm{pH}$ above 8 $(\mathrm{pH}=9.0)$ reduces the effectiveness of degradation. To evaluate the kinetics of 2-CP oxidation by persulfate the experimental data were fitted to a first-order rate model (Eq. 9):

$$
\ln \left(C_{\mathrm{t}} / C_{0}\right)=-k_{1} t
$$

Straight line plots of $\ln \left(C_{t} / C_{0}\right)$ vs. $t$ were used to determine the rate constants $k_{1}$ and correlation

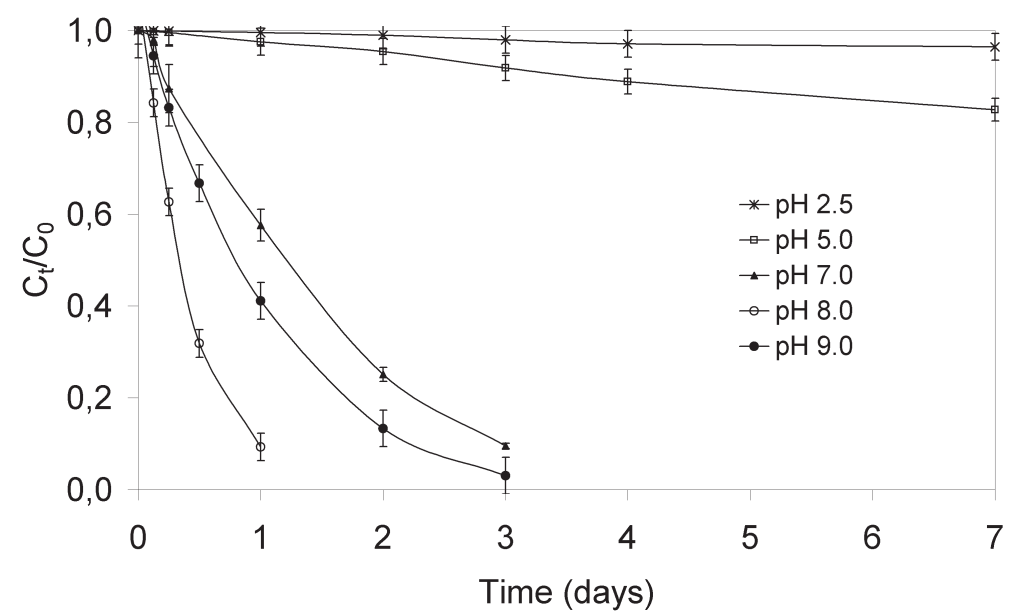

Figure 1. The effect of solution $\mathrm{pH}$ on the degradation of 2-chlorophenol. Experimental conditions:

2-CP $=0.1 \mathrm{mmol} \mathrm{L}^{-1}$, persulfate $=10 \mathrm{mmol} \mathrm{L}^{-1}$, temp $20^{\circ} \mathrm{C}$. Data points and error bars represent averages and standard deviations of samples from replicate reactors 
coefficients $R^{2}$. Half-life of 2-CP degradation was calculated from the following formula:

$$
t_{1 / 2}=\ln (2) / k_{1}
$$

The lowest rate constant $\left(k_{1}\right)$ was observed at pH $2.5\left(0.004\right.$ day $\left.^{-1}\right)$ followed by those at $\mathrm{pH} 5.0$ $\left(0.023\right.$ day $\left.^{-1}\right), \mathrm{pH} 7.0\left(0.784\right.$ day $\left.^{-1}\right), \mathrm{pH} 9.0$ (1.089 day $\left.^{-1}\right)$ and $\mathrm{pH} 8.0\left(2.321 \mathrm{day}^{-1}\right)$. The 2-CP halflives at $\mathrm{pH}$ 2.5, 5.0, 7.0, 8.0 and 9.0 were 173, 30, $0.88,0.30$ and 0.64 days, respectively.

Similar results were observed by Liang et al. [2007] who investigated the influence of $\mathrm{pH}$ on persulfate oxidation of trichloroethylene at ambient temperature. Ghauch et al. [2012a] reported that the optimum $\mathrm{pH}$ for ibuprofen thermal oxidation is $\mathrm{pH}=7.0$ followed by $\mathrm{pH}=9.0$ and $\mathrm{pH}=$ 4.0. On the other hand, the same authors [Ghauch et al. 2012b] reported that the least efficient system for methylene blue degradation is the one under basic conditions, whereas at neutral $(\mathrm{pH} 7.0)$ and acidic $\mathrm{pH}(\mathrm{pH} 4.0)$, the oxidation process is more effective. Huang et al. [2002] showed that the reaction rate of heat-assisted persulfate oxidation of methyl tert-butyl ether decreased with the increase in the $\mathrm{pH}$ value. Accordingly, based on the literature, the $\mathrm{pH}$ can differently affect organic compounds degradation and therefore common $\mathrm{pH}$ effect cannot be expected.

Under $\mathrm{pH}$ conditions close to neutral sulfate radicals could react with $\mathrm{H}_{2} \mathrm{O}$ to generate hydroxyl radicals (Eq. 3) whereas at high $\mathrm{pH}$ values $(\mathrm{pH}>$ 8.5) significant concentration of $\mathrm{SO}_{4}{ }^{2-}$ present at the solution may scavenge hydroxyl radicals and, in consequence, may slow down oxidation compared to the neutral $\mathrm{pH}$ medium. In our study we observed that acidic $\mathrm{pH}$ caused more inhibition of 2-CP oxidation by persulfate than alkaline medium. Under acidic conditions, an acidic catalysis may transformed persulfate to $\mathrm{SO}_{4}{ }^{-}$. As suggested by Liang et al. [2007], the higher concentration of $\mathrm{SO}_{4}^{-{ }^{-}}$may favor radical with radical reactions or radical with radical scavenger reactions (Eq. 11 and 12) over radical with organic compound reactions.

$$
\begin{gathered}
\mathrm{SO}_{4}{ }^{-{ }^{-}+} \mathrm{SO}_{4}{ }^{-{ }^{-}} \rightarrow \mathrm{S}_{2} \mathrm{O}_{8}{ }^{2-} \\
\mathrm{SO}_{4}{ }^{--}+\mathrm{S}_{2} \mathrm{O}_{8}{ }^{2-} \rightarrow \mathrm{SO}_{4}{ }^{2-}+\mathrm{S}_{2} \mathrm{O}_{8}{ }^{--}
\end{gathered}
$$

As shown above, the $\mathrm{pH}$ played an important role in the 2-CP oxidation by persulfate, the best results were obtained when the initial solution $\mathrm{pH}$ was 8.0.

\section{Effect of initial persulfate concentration}

The effect of initial persulfate concentration on the degradation of 2-chlorophenol was investigated at $\mathrm{pH} 8.0\left(20{ }^{\circ} \mathrm{C}\right)$ for a range of $2-\mathrm{CP} /$ $\mathrm{S}_{2} \mathrm{O}_{8}{ }^{2-}$ molar ratios from $1 / 10$ to $1 / 400$. Results are shown in Figure 2. The calculated rate constants, half-lives, correlation coefficients and degradation percentages of 2-CP after six hours are presented in Table 1.

The rate of 2-CP oxidation increased with the increasing concentration of persulfate in the solution. The reaction rate constant $k_{1}$ increased from $0.014(1 / 10)$ to $0.313 \mathrm{~h}^{-1}(1 / 400)$. The biggest difference in the $k_{1}$ values was observed between the curves obtained for a molar ratio of $1 / 100$ and $1 / 200$. The differences between the results obtained when the molar ratio used was $1 / 200$, $1 / 300$ and $1 / 400$ are not as significant.

For comparison, a sample in water $(\mathrm{pH}=2.5)$ with 2-CP to $\mathrm{S}_{2} \mathrm{O}_{8}^{2-}$ molar ratio of $1 / 200$ was also

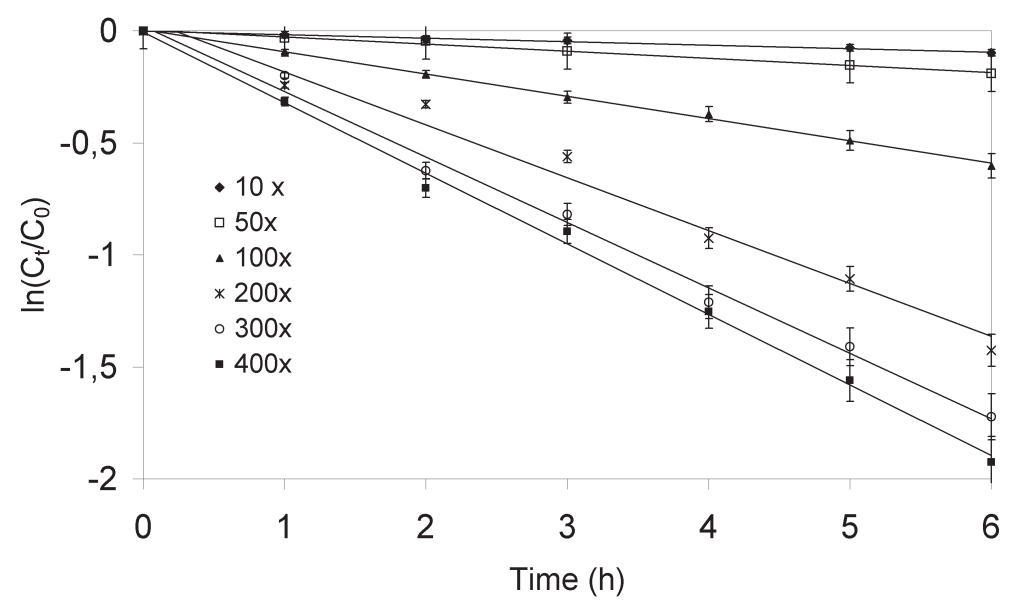

Figure 2. The effect of persulfate excess on the degradation of 2-chlorophenol. Experimental conditions: the initial concentration of $2-\mathrm{CP}$ was $0.1 \mathrm{mmoL}^{-1}$, the molar ratio 2-CP/persulfate was $1 / 10,1 / 50,1 / 100,1 / 200,1 / 300$ and $1 / 400, \mathrm{pH} 8.0$, temp. $20^{\circ} \mathrm{C}$ ) 
Table 1. Effect of persulfate concentration on the degradation of $2-\mathrm{CP}$ at $\mathrm{pH} 8.0$ and at $20^{\circ} \mathrm{C}$. The initiatial concentration of 2-CP was $0.1 \mathrm{mmoL}^{-1}$

\begin{tabular}{|c|c|c|c|c|}
\hline $\begin{array}{c}2-\mathrm{CP} / \text { persulfate molar } \\
\text { ratio }\end{array}$ & $\begin{array}{c}k_{1} \\
\left(\mathrm{~h}^{-1}\right)\end{array}$ & $\begin{array}{c}t_{1 / 2} \\
(\mathrm{~h})\end{array}$ & $R^{2}$ & $\begin{array}{c}\text { of degradation }^{\text {a) }} \\
(\%)\end{array}$ \\
\hline $1 / 10$ & 0.014 & 49.76 & 0.990 & 8.11 \\
\hline $1 / 50$ & 0.030 & 23.66 & 0.979 & 17.04 \\
\hline $1 / 100$ & 0.088 & 7.886 & 0.988 & 71.76 \\
\hline $1 / 200$ & 0.217 & 3.203 & 0.990 & 72.85 \\
\hline $1 / 200$ b) & 0.005 & 330.3 & 0.978 & 0.41 \\
\hline $1 / 300$ & 0.268 & 2.593 & 0.991 & 79.06 \\
\hline $1 / 400$ & 0.313 & 2.220 & 0.989 & 85.06 \\
\hline
\end{tabular}

a) after 6 hours

b) at $\mathrm{pH} 2.5$

prepared. The $k_{1}$ and the half-life values were $0.005 \mathrm{~h}^{-1}$ and $330 \mathrm{~h}$, respectively. The $k_{1}$ value was more than 40 times lower than those obtained at $\mathrm{pH}$ 8.0.

\section{Effect of temperature}

The experiments were carried out in the phosphate buffer $(\mathrm{pH}=8.0)$ at $20,30,40$ and $50{ }^{\circ} \mathrm{C}$. Three cases with different $2-\mathrm{CP} /$ persulfate molar ratios $(1 / 100,1 / 200$ and 1/400) were examined. The results in Figure 3 indicated that 2-chlorophenol was rapidly degraded with persulfate under the experimental conditions. Details are presented in Table 2. As can be seen, the reaction was significantly influenced by temperature and oxidant concentration. The higher concentration of persulfate and higher temperature result in a faster degradation of 2-chlorophenol.

For the control, two samples in water $(\mathrm{pH}=$ 2.5 ) at $2-\mathrm{CP} /$ persulfate molar ratio $1 / 200$ and at two temperatures $\left(40\right.$ and $\left.50^{\circ} \mathrm{C}\right)$ were also tested. The obtained values of the degradation rate for aqueous solutions were slightly lower than those obtained for the corresponding samples in the phosphate buffer $(\mathrm{pH}=8.0)$. The degradation rates of $2-\mathrm{CP}$ in water and in phosphate buffer were 0.712 and $0.769 \mathrm{~h}^{-1}$ at $40{ }^{\circ} \mathrm{C}$ and 1.565 and $1.661 \mathrm{~h}^{-1}$ at $50{ }^{\circ} \mathrm{C}$, respectively. This suggests that thermal-activation is much more effective than alkaline-activation.

The temperature dependency of the kinetic constant was additionally evaluated using the Arrhenius equation:

$$
\ln k_{1}=\ln A-E_{\mathrm{A}} / R T
$$

where: $A$ - the Arrhenius constant,

$E_{\mathrm{A}}$ - the activation energy $\left(\mathrm{kJ} \mathrm{mol}^{-1}\right)$,

$R$ - the universal gas constant $(8.314 \mathrm{~kJ}$

$\mathrm{mol}^{-1} \mathrm{~K}^{-1}$ ),

$T$ - the temperature (K).
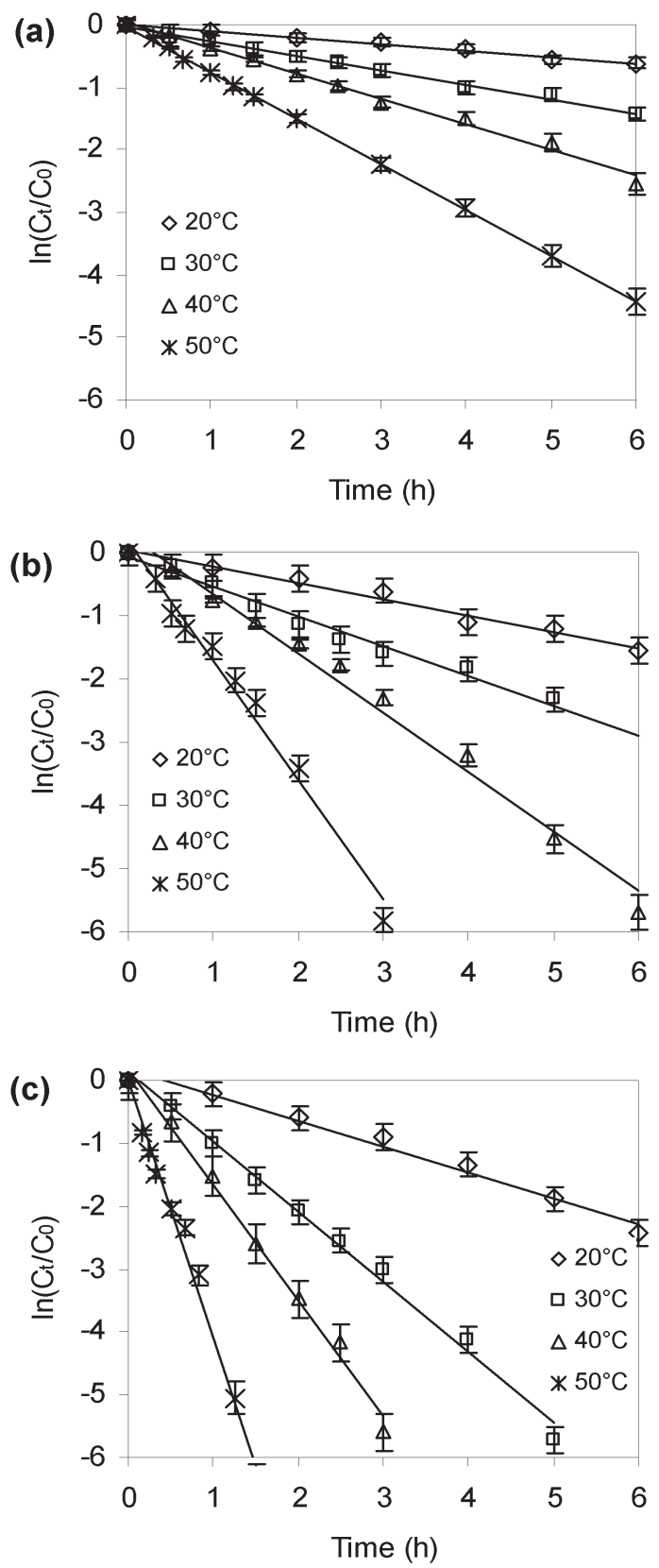

Figure 3. The effect of temperature on the degradation of 2-chlorophenol by persulfate at 2-CP/persulfate molar ratio of 1/100 (a), 1/200 (b) and 1/400 (c). Experimental conditions: $2-\mathrm{CP}=0.1 \mathrm{mmol} \mathrm{L}^{-1}, \mathrm{pH} 8.0$ 
Table 2. Rate constants of heat-assisted persulfate oxidation of 2-chlorophenol in phosphate-buffered solutions ( $\mathrm{pH}$ 8.0) under various oxidant concentrations and various temperatures. The initial concentration of 2-CP was $0.1 \mathrm{mmoL}^{-1}$

\begin{tabular}{|c|c|c|c|c|c|c|}
\hline $\begin{array}{c}2-\mathrm{CP} / \text { persulfate molar } \\
\text { ratio }\end{array}$ & $\begin{array}{l}\text { temp. } \\
\left({ }^{\circ} \mathrm{C}\right)\end{array}$ & $\begin{array}{c}k_{1} \\
\left(\mathrm{~h}^{-1}\right)\end{array}$ & $\begin{array}{l}t_{1 / 2} \\
(\mathrm{~h})\end{array}$ & $R^{2}$ & $\begin{array}{c}E_{\mathrm{A}} \\
\left(\mathrm{kJ} \mathrm{mol}^{-1}\right)\end{array}$ & $R^{2 \text { a) }}$ \\
\hline \multirow{4}{*}{$1 / 100$} & 20 & 0.095 & 7.345 & 0.989 & \multirow{4}{*}{50.225} & \multirow{4}{*}{0.988} \\
\hline & 30 & 0.228 & 3.047 & 0.990 & & \\
\hline & 40 & 0.373 & 1.860 & 0.991 & & \\
\hline & 50 & 0.669 & 1.038 & 0.986 & & \\
\hline \multirow{6}{*}{$1 / 200$} & 20 & 0.221 & 3.299 & 0.987 & \multirow{6}{*}{52.519} & \multirow{6}{*}{0.990} \\
\hline & 30 & 0.480 & 1.446 & 0.989 & & \\
\hline & 40 & 0.769 & 0.902 & 0.991 & & \\
\hline & $40^{b)}$ & 0.712 & 0.975 & 0.996 & & \\
\hline & 50 & 1.661 & 0.417 & 0.985 & & \\
\hline & $50^{\text {b) }}$ & 1.565 & 0.443 & 0.988 & & \\
\hline \multirow{4}{*}{$1 / 400$} & 20 & 0.316 & 2.198 & 0.990 & \multirow{4}{*}{66.532} & \multirow{4}{*}{0.986} \\
\hline & 30 & 0.995 & 0.696 & 0.984 & & \\
\hline & 40 & 1.719 & 0.403 & 0.991 & & \\
\hline & 50 & 4.380 & 0.158 & 0.990 & & \\
\hline
\end{tabular}

a) $R^{2}$ for Arrhenius plot

b) in water ( $\mathrm{pH} 2.5)$

The straight line plots of $\ln k_{1}$ against $1 / T$ were constructed (Figure 4). The Arrhenius constants and activation energies were obtained from the intercept and slope in linear regression result and are listed in Table 2. For investigated 2-CP/persulfate molar ratios of $1 / 100,1 / 200$ and $1 / 400$, the calculated activation energies were 50.225 , 52.519 and $66.532 \mathrm{~kJ} \mathrm{~mol}^{-1}$, respectively. $E_{\mathrm{A}}$ values increased with concentration of persulfate in the solution.

A similar relationship was observed by Ghauch et al. [2012b]. They investigated degradation of methylene blue by heated persulfate and observed higher values of activation energy for more concentrated dye/persulfate system. The authors suggested that for highly charged solutions, dilution would make the treatment process faster due to a decrease in the activation energy of the chemical reaction required for dye degradation by persulfate.

\section{Effect of $\mathrm{Fe}^{2+}$ and $\mathrm{Cu}^{2+}$ ions on 2-CP degradation}

The experiments were carried out at constant initial concentrations of 2-CP $\left(0.1 \mathrm{mmol} \mathrm{L}^{-1}\right)$ and persulfate $\left(20 \mathrm{mmol} \mathrm{L}^{-1}\right)$ and at different concentrations of $\mathrm{Fe}^{2+}$ or $\mathrm{Cu}^{2+}$. The molar ratios of 2-CP/ persulfate/metal ion were $1 / 200 / 0.5,1 / 200 / 1$ and $1 / 200 / 2$. As can be seen in Figure 5, increasing the amount of iron ions accelerated the 2-CP/persulfate reaction. Calculated first-order kinetic constants were $0.032,0.043$ and $0.078 \mathrm{~h}^{-1}$ for 0.05 , 0.1 and $0.2 \mathrm{mmol} \mathrm{L}^{-1}$ of $\mathrm{Fe}^{2+}$, respectively. A similar relationship was observed after the application of copper(II) ions, but the $k_{1}$ values were smaller. This suggest that the persulfate is activated more effectively by ferrous than copper ions.

For comparison, two samples with $\mathrm{Fe}^{2+}$ and $\mathrm{Cu}^{2+}$ with 2-CP/persulfate/metal ion ratio of $1 / 200 / 2$, at $50{ }^{\circ} \mathrm{C}$ were studied. The first-order rate constants and half-lives were $7.029 \mathrm{~h}^{-1}$ and $0.099 \mathrm{~h}\left(\mathrm{Fe}^{2+}\right)$, and $6.361 \mathrm{~h}^{-1}$ and $0.109 \mathrm{~h}\left(\mathrm{Cu}^{2+}\right)$, respectively. Increasing the temperature from 20 to $50{ }^{\circ} \mathrm{C}$ resulted in about 90 -fold increase of $k_{1}$ value in the presence of $\mathrm{Fe}^{2+}$ and about 120-fold in the presence of $\mathrm{Cu}^{2+}$ ions. Synergistic activation of persulfate by heat and $\mathrm{Fe}^{2+}$ was more effective than by heat and $\mathrm{Cu}^{2+}$, and much more effective than by heat and alkali.

\section{CONCLUSIONS}

The paper compares the most popular ways of persulfate activation and their influence on the 2-chlorophenol degradation. The 2-CP oxidation kinetics and its affecting factors including $\mathrm{pH}$, oxidant excess, ferrous and copper ions content, as well as temperature were particularly 
Table 3. The effect of $\mathrm{Fe}^{2+}$ and $\mathrm{Cu}^{2+}$ concentrations on the 2-chlorophenol degradation at $\mathrm{pH} 8.0$ and at $20^{\circ} \mathrm{C}(2-\mathrm{CP}$ concentration $=0.1 \mathrm{mmol} \mathrm{L}^{-1}$, persulfate concentration $=20 \mathrm{mmol} \mathrm{L}^{-1}$ )

\begin{tabular}{|c|c|c|c|c|}
\hline 2-CP/persulfate/Me ${ }^{2+}$ molar ratio & $\begin{array}{c}k_{1} \\
\left(\mathrm{~h}^{-1}\right)\end{array}$ & $\begin{array}{c}t_{1 / 2} \\
(\mathrm{~h})\end{array}$ & $R^{2}$ & $\begin{array}{c}\% \text { of degradation }{ }^{\text {a) }} \\
(\%)\end{array}$ \\
\hline \multicolumn{5}{|c|}{ Ferrous ions } \\
\hline $1 / 200 / 0.5$ & 0.032 & 21.74 & 0.989 & 21.67 \\
\hline $1 / 200 / 1$ & 0.043 & 16.36 & 0.989 & 40.01 \\
\hline $1 / 200 / 2$ & 0.078 & 8.939 & 0.995 & - \\
\hline $1 / 200 / 2^{\mathrm{b})}$ & 7.029 & 0.099 & 0.998 & 11.47 \\
\hline \multicolumn{7}{|c|}{ Copper ions } \\
\hline $1 / 200 / 0.5$ & 0.020 & 35.75 & 0.987 & 18.89 \\
\hline $1 / 200 / 1$ & 0.034 & 20.91 & 0.990 & 29.52 \\
\hline $1 / 200 / 2$ & 0.055 & 12.77 & 0.989 & - \\
\hline
\end{tabular}

a) after 6 hours

b) at $50^{\circ} \mathrm{C}$

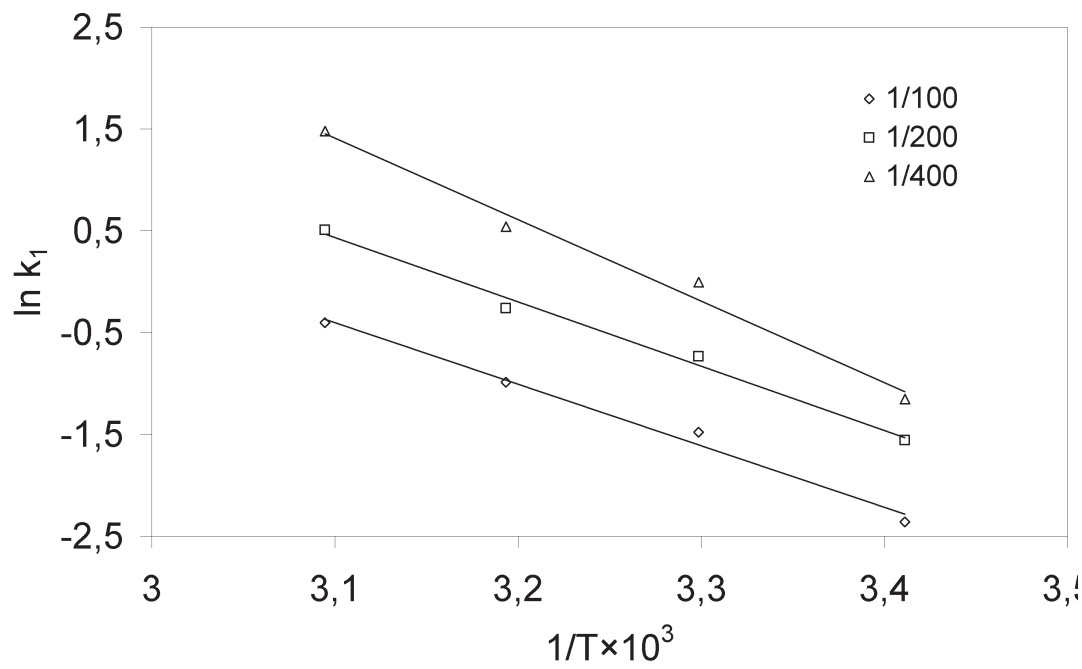

Figure 4. Arrhenius plots for 2-chlorophenol degradation under different persulfate excess
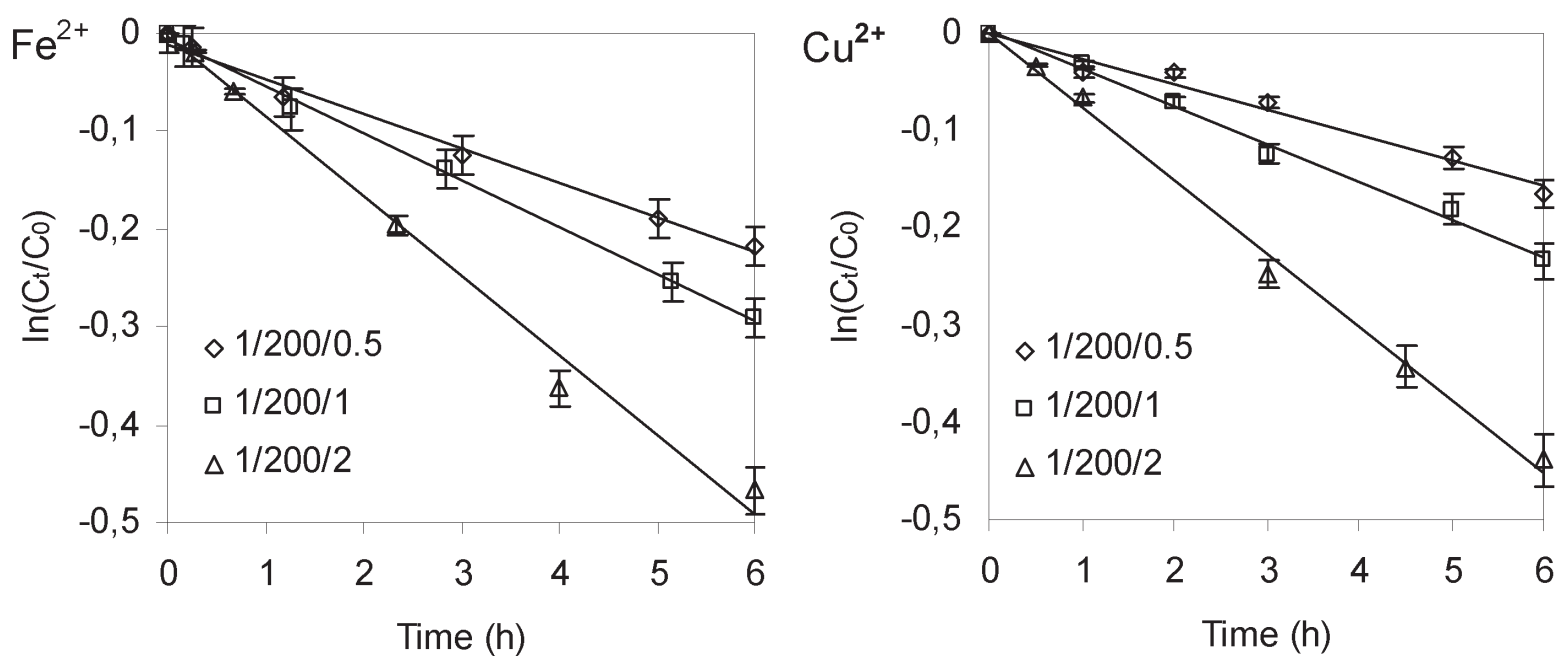

Figure 5. Degradation of 2-chlorophenol by persulfate activated by different concentrations of $\mathrm{Fe}^{2+}$ and $\mathrm{Cu}^{2+}$ at $\mathrm{pH}$ 8.0 and $20^{\circ} \mathrm{C}$. The initial concentration of $2-\mathrm{CP}$ was $0.1 \mathrm{mmol} \mathrm{L}^{-1}$, and that of persulfate was $20 \mathrm{mmol} \mathrm{L}^{-1}$ 
examined. The results indicated that the reaction is highly influenced by these factors, however, thermal activation is a key factor. The best results were achieved when used at the same time two types of persulfate activation - heat/alkali, heat $/ \mathrm{Cu}^{2+}$ or heat $/ \mathrm{Fe}^{2+}$. Under the optimal conditions, at $\mathrm{pH} 8.0$ in the presence of ferrous ions and at $50{ }^{\circ} \mathrm{C}$, complete degradation of 2-chlorophenol was achieved after about 30 minutes.

\section{Acknowledgements}

This work was partially supported by Ministry of Science and Higher Education (Poland) project RMN 971.

\section{REFERENCES}

1. Ahlborg U.G., Thunberg T.M. 1980. Chlorinated phenols: occurrence, toxicity, metabolism, and environmental impact. Crit. Rev. Toxicol., 7, 1-35.

2. Armenante P.M., Kafkewtiz D., Lewandowski G.A., Jou C.J. 1999. Anaerobic-aerobic treatment of halogenated phenolic compounds. Water Res., 33, 681-692.

3. Berlin A.A. 1986. Kinetics of radical-chain decomposition of persulfate in aqueous solutions of organic compounds. Kinet. Catal., 27, 34-39.

4. Cao J., Zhang W.X., Brown D.G., Sethi D. 2008. Oxidation of lindane with Fe(II)-activated sodium persulfate. Environ. Eng. Sci., 25, 221-228.

5. Czaplicka M. 2004. Sources and transformations of chlorophenols in the natural environment. Sci. Total Environ., 322, 21-39.

6. Fang G.D., Dionysiou D.D., Zhou D.M., Wang Y., Zhu X.D., Fan J.X., Cang L., Wang Y.J. 2013. Transformation of polychlorinated biphenyls by persulfate at ambient temperature. Chemosphere, 90, 1573-1580.

7. Ghauch A., Tuqan A.M., Kibbi N. 2012a. Ibuprofen removal by heated persulfate in aqueous solution: a kinetics study. Chem. Eng. J., 197, 483-492.

8. Ghauch A., Tuqan A.M., Kibbi N., Geryes S. 2012b. Methylene blue discoloration by heated persulfate in aqueous solution. Chem. Eng. J., 213, 259-271.

9. Huang K.C., Couttenye R.A., Hoag G.E. 2002. Kinetics of heat-assisted persulfate oxidation of methyl tert-butyl ether (MTBE). Chemosphere, 49, 413-420.

10. Jiang X., Wu Y., Wang P., Li H., Dong W. 2013. Degradation of bisphenol $\mathrm{A}$ in aqueous solution by persulfate activated with ferrous ion. Environ. Sci. Pollut. Res., 20, 4947-4953.
11. Kolthoff I.M., Medalia A.I., Raaen H.P. 1951. The reaction between ferrous ion and peroxides IV, reaction with potassium persulfate. J. Am. Chem. Soc., 73, 1733-1740.

12. Krzemińska D., Neczaj E., Borowski G. 2015. Advanced oxidation processes for food industrial wastewater decontamination. J. Ecol. Eng., 16(2), 61-71.

13. Kucharska M., Naumczyk J. 2009. Degradation of selected chlorophenols by advanced oxidation processes. Environ. Prot. Eng., 35, 47-55.

14. Kuśmierek K., Dąbek L., Świątkowski A. 2015. A comparative study on oxidative degradation of 2,4-dichlorophenol and 2,4-dichlorophenoxyacetic acid by ammonium persulfate. Desalin. Water Treat., (in press) doi: 10.1080/19443994. 2015.1017327

15. Kuśmierek K., Świątkowski A. 2012. Removal of 4-chlorophenol from water by advanced oxidation processes with hydrogen peroxide. Przem. Chem., 91(12), 2422-2424.

16. Latimer W.M. 1952. The oxidation states of the elements and their potentials in aqueous solutions. Englewood Cliffs: New York.

17. Liang C., Guo Y.Y., Chien Y.C., Wu Y.J. 2010. Oxidative degradation of MTBE by pyrite-activated persulfate: proposed reaction pathways. Ind. Eng. Chem. Res., 49, 8858-8864.

18. Liang C., Guo Y.Y., Pan Y.R. 2015. A study of the applicability of various activated persulfate processes for the treatment of 2,4-dichlorophenoxyacetic acid. Int. J. Environ. Sci. Technol., 11, 483-492.

19. Liang C., Wang Z.S., Bruell C.J. 2007. Influence of $\mathrm{pH}$ on persulfate oxidation of TCE at ambient temperatures. Chemosphere, 66, 106-113.

20. Liang H., Zhang Y., Huang S., Hussain I. 2013. Oxidative degradation of p-chloroaniline by copper oxidate activated persulfate. Chem. Eng. J., 218, 384-391.

21. Liu C.S., Shih K., Sun C.X., Wang F. 2012. Oxidative degradation of propachlor by ferrous and copper ion activated persulfate. Sci. Total Environ., 416, 507-512.

22. Mora V.C., Rosso J.A., Martire D.O., Gonzalez M.C. 2011. Phenol depletion by thermally activated peroxydisulfate at $70{ }^{\circ} \mathrm{C}$. Chemosphere, 84 , 1270-1275.

23. Oh S.Y., Kang S.G., Kim D.W., Chiu P.C. 2011. Degradation of 2,4-dinitrotoluene by persulfate activated with iron sulfides. Chem. Eng. J., 172, 641-646.

24. Oh S.Y., Kim H.W., Park J.M., Park H.S., Yoon C. 2009. Oxidation of polyvinyl alcohol by persulfate activated with heat, $\mathrm{Fe}^{2+}$, and zero-valent iron. J. Hazard. Mater., 168, 346-351. 
25. Olmez-Hanci T., Arslan-Alaton I. 2013. Comparison of sulfate and hydroxyl radical based advanced oxidation of phenol. Chem. Eng. J., 224, 10-16.

26. Olmez-Hanci T., Arslan-Alaton I., Genc B. 2013. Bisphenol A treatment by the hot persulfate process: oxidation products and acute toxicity. J. Hazard. Mater., 263, 283-290.

27. Pera-Titus M., Garcia-Molina V., Banos M., Jimenez J., Esplugas S. 2004. Degradation of chlorophenols by means of advanced oxidation processes: a general review. Appl. Catal. B: Environ., 47, 219-256.

28. Rastogi A., Al-Abed S.R., Dionysiou D.D. 2009. Effect of inorganic, synthetic and naturally occurring chelating agents on $\mathrm{Fe}(\mathrm{II})$ mediated advanced oxidation of chlorophenols. Water Res., 43, 684-694.
29. Tan C., Gao N., Chu W., Li C., Templeton M.R. 2012. Degradation of diuron by persulfate activated with ferrous ion. Sep. Purif. Technol., 95, 44-48.

30. Yang S., Wang P., Yang X., Shan L., Zhang W., Shao X., Niu R. 2010. Degradation efficiencies of azo dye acid orange 7 by the interaction of heat, UV and anions with common oxidants: persulfate, peroxymonosulfate and hydrogen peroxide. J. Hazard. Mater., 179, 552-558.

31. Zhao J., Zhang Y., Quan X., Chen S. 2010. Enhanced oxidation of 4-chlorophenol using sulfate radicals generated from zero-valent iron and peroxydisulfate at ambient temperature. Separ. Purif. Technol., 71, 302-307. 